\title{
Relationship between Economic Growth, Unemployment and Poverty: Analysis at Provincial Level in Vietnam
}

\author{
Nguyen Hoang Quy ${ }^{1}$ \\ ${ }^{1}$ National Academy of Public Administration, Hanoi, Vietnam \\ Correspondence: Nguyen Hoang Quy, Ph. D., National Academy of Public Administration, 77 Nguyen Chi Thanh, \\ Dong Da District, Hanoi, Vietnam. Tel: 84-43-764-3219. E-mail: nghoangquy@ yahoo.com
}

Received: October 22, 2016

Accepted: November 2, 2016

Online Published: November 20, 2016

doi:10.5539/ijef.v8n12p113

URL: http://dx.doi.org/10.5539/ijef.v8n12p113

\begin{abstract}
This empirical study analyzes the relationship between economic growth, unemployment and poverty at provincial level in Vietnam. The study is conducted on a sample of 245 year observations in 63 Vietnam provinces for the period of 2012-2015. The research results show that: Firstly, public investment has a positive impact on economic growth. Secondly, poverty, and export \& import have a negative impact on unemployment. Thirdly, public investment has a significant and positive impact on unemployment. Fourthly, unemployment; export \& import; and public investment have a negative impact on poverty. On the basis of our findings, we suggest 03 groups of recommendations for sustainable economic growth, poverty reduction, and unemployment reduction of Vietnam provinces.
\end{abstract}

Keywords: economic growth, unemployment, poverty, province, provincial analysis, Vietnam

\section{Introduction}

As an important macroeconomic indicator, GDP growth rate is used to measure development achievements of a country in a certain period. Vietnam economy growth has been stable with average growth rate of $6.29 \%$ in the last ten years despite of the global financial and sovereign debt crisis. This is a significant achievement in the context of the economic difficulties nowadays.

However, the integration into the world economy and transition to a market economy have several limits, especially unequal socioeconomic development among areas and different population groups. This results the difficulties in production and people's life due to not keeping up with changes. Thus, economic growth has to be associated with social progress by decreasing poverty rate and unemployment rate.

There are many studies on economic growth, poverty and unemployment in Vietnam. However, the ones focus on individually studying the issues above. This paper aims to study the relationship between economic growth, unemployment and poverty at provincial level in Vietnam. The number of year observations is 245 . We conduct regression analysis with 06 variables, including (i) Economic growth, (ii) Poverty rate, (iii) Unemployment rate, (iv) Public expenditure, (v) Export \& Import value, and (vi) Public investment, of 63 Vietnam provinces in the period of 2012-2015.

\section{Theoretical Framework}

\subsection{Concepts}

Economic growth is defined as "a long-term rise in capacity to supply increasingly diverse economic goods to its population; this growing capacity is based on advancing technology and the institutional and ideological adjustments that it demands." Economic growth refers to a country's an increase in output, economic goods provision, and advanced technology presence. Herwartz and Niebuhr (2011) believe that economic growth involves in the rise of an economic capacity to produce goods and services for improving the well-being of the community.

There are a variety of empirical studies of economic growth indicating different results. Many researches show that economic growth does not signify improvement in the well-being of the community (Neto \& Silva, 2013). Sezgin et al. (2013) suggests three major definitions of economic growth, including: nominal, output real value, and per capita value definitions. 
Galbis (2012) defines unemployment as "involuntary idleness of a person willing to work at the prevailing rate of pay but unable to find it." This indicates that voluntarily unemployed people not wanting to work, and not being prepared to work at the prevailing wage rate, are not to be considered as unemployed people. Moore and Donaldson (2016) believe that poverty is lack of adequate resources for obtaining and consuming a certain quantity of necessary goods and services, including: food, shelter and clothing. However, it is difficult to determine objective minimum and minimum standards for basic necessities because they depend on individual taste, cultural values, and socio-economic conditions within a certain society.

Other definition of poverty is that poverty is the maximum income proportion that a family spends on certain subsistence commodities (Alberto, 2014). The other approach is that poverty refers to the living standards that prevail in a certain society. This approach indicates the different perceptions of acceptable minimum living standards. In general, poverty refers to low calorie intake, poor living conditions, poor health facilities, unemployment, and low income.

\subsection{Relationship between Economic Growth, Unemployment and Poverty}

\subsubsection{Relationship between Economic Growth and Unemployment}

Economic growth and unemployment are often regarded as two separate research areas which deal with different issues. The first research of the relationship between economic growth and unemployment was conducted in the mid-20th century by Harrod and Domar. However, their contribution was an isolated example because the Solow model introduced new ideas into the debate on economic growth, at the same time relegating the studies of the growth-unemployment relationship as less relevant (Parello, 2010).

The relationship between growth and unemployment was empirically confirmed by Okun in 1962 (Okun, 1962) and is still recognized as one of the fundamental macroeconomic laws. He shows the negative relationship between production growth rate and unemployment rate, which in the case of the US economy means that a $1 \%$ decrease in real production compared to its potential value leads to a $0.5 \%$ increase in the unemployment rate (Sezgin et al., 2013).

The nature of the relationship between the variables is not universally accepted by economists. Some researches confirm a negative short-term relationship between economic growth and unemployment, other negates its existence either entirely or under certain conditions, questioning whether the relationship is actually a law.

\subsubsection{Relationship between Economic Growth and Poverty}

Sustainable economic growth has a significant impact on poverty reduction. However, in fact, economic growth affects poverty in various directions. According to Al-Habees and Rumman (2012), in India in the 70s, and in the Philippines in the 80s and 90s, poverty was significantly improved despite achieving only modest growth or even a fall in per capita income. On the other hand, in Thailand in the 80s, Malaysia in the 90s, and in Sri Lanka in the 90s, there is a failure in poverty reduction despite high economic growth and per capita income. Bui and Pham (2009) said that in Vietnam from the 90s to 2000s, high economic growth significantly contributed to poverty reduction (an increase in GDP per capita by one percent reduced poverty by 1.3 percent in 1993-1998). However, an increase in GDP per capita by one percent reduced poverty by 0.06 percent in 1998-2002. Hence, a key lesson that can be drawn is that economic growth is a necessary condition for poverty reduction, but it is not sufficient.

In the opposite direction, poverty is a major constraint on economic growth. Specifically, the poor often has poor health negatively affecting the productivity and skill, this reduces production capacity of a country. Besides, saving and investment is limited due to poverty weakening economic growth. In addition, tight collateral conditions for bank borrowers decreases the access to financial markets of the poor. Thus, the poor does not have the opportunity to save money. Low growth rate of per capita income increases poverty. In general, poverty reduction creates an environment conducive to economic growth. Effective socio-economic policies (including investment in the infrastructure of primary education, health care ...) contribute to raising the incomes of the poor by increasing production capacity of a country.

\subsection{Empirical Studies of Relationship between Economic Growth, Unemployment and Poverty}

Al-Habees and Rumman (2012) believe that growth and unemployment move in the opposite direction. All things being equal, the higher growth rate is, the lower unemployment rate is. Unemployment increase leads to decrease in output and economic growth, all things being equal. This means that there is a negative relationship between economic growth and unemployment. Thus, for reducing unemployment, economic growth policies should be formulated and put in place. According to the classical view, this contributes to an increase in goods and service demand and labor demand. 
A number of empirical evidences show a negative impact of economic growth on unemployment, and vice versa. In the Caribbean, countries with high growth rates (including Antigua and Barbuda, the Bahamas, Barbados, and St. Kitts and Nevis) have low unemployment rates (Nikolli, 2014).

In Nigeria, the high rate of economic growth between 1988 and 1992 was accompanied by decrease in unemployment rate (Amassoma et al., 2013). A major strategy of rapid economic growth and unemployment reduction is investment in human resource. A recent study of World Bank indicates that the most important factor of rapid economic growth and unemployment reduction in East Asian countries is investment in human capital (Al-Habees \& Rumman, 2012).

Marinko and Romina (2015) suggest that absolute poverty is measured by low income and low life expectancy. There is a significant negative relationship between poverty and economic growth. Marinko and Romina (2015) state that an inverse association between economic growth and poverty needs to be carefully qualified because of the differences in income distribution. However, many researchers agree that economic growth in the very long-term can eliminates absolute poverty (Al-Habees \& Rumman, 2012).

Economic growth plays an important role in poverty reduction by rising employment, increasing labor productivity and high real wages. For example, countries in the Caribbean of high growth rates and concentrating on human capital have relatively low poverty rates. However, poverty has increased in Caribbean countries that have low or negative growth rates for protracted periods (including Guyana, Haiti, Jamaica, Suriname and Trinidad and Tobago) (Nikolli, 2014). For economic growth to bring about poverty reduction, job creation for the poor people is very essential.

There is a positive relationship between high unemployment and widespread poverty. In most cases, people without regular employment or with only scattered part-time employment are among the very poor people. However, it would be wrong to believe that people who do not have a job is poor. These people are unemployed by definition, however they may not be poor (Amassoma et al., 2013).

\section{Methodology}

Secondary data were collected through domestic and international researches, curricula, journals... This research focuses on relationship between economic growth, unemployment and poverty at provincial level in Vietnam. We used regression method of 06 variables, including (i) economic growth, (ii) poverty rate, (iii) unemployment rate, (iv) Public expenditure, (v) Export \& Import value, (vi) Public investment of 63 Vietnam provinces in the period of 2013-2015. Number of year observations is 245 ( 07 eliminated ones due to insufficient information). In addition, we collected data from Statistical Yearbooks 2013-2015 of 63 Vietnam provinces. The data ensure fully reliable due to they are formal data published widely by Vietnam General Statistical Office. The monetary data (Public investment) and calculated based on monetary data (GDP growth rate) are adjusted according to the price of 2010 for removing inflation impact. The research sample profile is shown in the following table.

Table 1. Research sample profile

\begin{tabular}{lcccccc}
\hline & $\begin{array}{c}\text { Economic } \\
\text { growth }(\%)\end{array}$ & $\begin{array}{c}\text { Public expenditure } \\
\text { (billion VND) }\end{array}$ & $\begin{array}{c}\text { Export \& Import } \\
\text { Value (million USD) }\end{array}$ & $\begin{array}{c}\text { Unemployment } \\
\text { rate (\%) }\end{array}$ & $\begin{array}{c}\text { Poverty } \\
\text { rate (\%) }\end{array}$ & $\begin{array}{c}\text { Public investment } \\
\text { (billion VND) }\end{array}$ \\
\hline Average & 7.85 & 109,903 & 50,656 & 1.92 & 11.23 & 27,576 \\
Std. Deviation & 8.08 & $1,003,968$ & 195,542 & 1.07 & 8.39 & 46,963 \\
Min & $(10.69)$ & 4,716 & 0.35 & 0.14 & - & 3,580 \\
Max & 113.00 & $11,565,373$ & $1,398,985$ & 4.92 & 42.80 & 364,171 \\
Number & 245 & 245 & 245 & 245 & 245 & 245 \\
\hline
\end{tabular}

We establish 03 regression models with 03 dependent variables of Economic growth, Unemployment rate, and Poverty rate.

$$
\begin{aligned}
& \text { Model 1: } E C G_{t i}=a_{0}+a_{1} * P V R_{t i}+a_{2} * U E R_{t i}+a_{3} * \operatorname{LnPE}_{t i}+a_{4} * \operatorname{LnPEI}_{t i}+a_{5} * \operatorname{LnPI}_{t i}+\varepsilon \\
& \text { Model 2: } U E R_{t i}=a_{0}+a_{1} * E C G_{t i}+a_{2} * P V R_{t i}+a_{3} * L n P E_{t i}+a_{4} * L n P E I_{t i}+a_{5} * \operatorname{LnPI}_{t i}+\varepsilon \\
& \text { Model 3: } P V R_{t i}=a_{0}+a_{1} * E C G_{t i}+a_{2} * U E R_{t i}+a_{3} * L n P E_{t i}+a_{4} * \operatorname{LnPEI}_{t i}+a_{5} * \operatorname{LnPI}_{t i}+\varepsilon
\end{aligned}
$$

With i: from 1 to 245 ;

t: from 2012 to 2015 ;

$\mathrm{ECG}_{\mathrm{ti}}$ : EConomic Growth or GDP growth in year t of Vietnam province i; 
$\mathrm{PVR}_{\mathrm{ti}}$ : PoVerty rate in year $\mathrm{t}$ of Vietnam province $\mathrm{i}$;

$\mathrm{UER}_{\mathrm{ti}}:$ UnEmployment rate in year $\mathrm{t}$ of Vietnam province $\mathrm{i}$;

$\operatorname{LnPE}_{\mathrm{ti}}$ : Natural logarithm of Public expenditure in year $t$ of Vietnam province i;

$\mathrm{LnPEI}_{\mathrm{ti}}$ : Natural logarithm of Export \& Import value in year t of Vietnam province i;

$\mathrm{LnPI}_{\mathrm{ti}}$ : Natural logarithm of Public investment in year $\mathrm{t}$ of Vietnam province i;

$\mathrm{a}_{0}, \mathrm{a}_{1}, \ldots, \mathrm{a}_{5}$ : coefficients to estimate;

$\varepsilon$ : error term.

\section{Research Results}

\subsection{Model 1 Where Economic Growth Is Dependent Variable}

The model is statistically significant at the significance level of $95 \%$ (sig. F-test $=0.038$ ). However, Adjusted R Square is low (2.8\%), so this model indicates inefficient results of GDP growth change. According to our results, public investment has a positive impact on economic growth with sig. t-test $<1 \%$, and the correlation coefficient of $0.258>0$. This means the higher public investment is, the higher economic growth is.

Investment is considered as the major engine of economic growth. The relationship between investment and economic development is studied in a variety of theoretical and empirical researches. Specifically, in developed nations, public investment accounts for a small proportion of all investment in the economy by supporting private sector and investing in risky fields. On the other hand, the State, in developing nations, plays an essential role in all economic activities. This results a great proportion of public investment of all investment. Thus, the regression result is relevant to Vietnam economy.

The other dependent variables of unemployment rate, poverty rate, public expenditure, and export \& import value do not have significant impact on economic growth of Vietnam provinces (sig. t-test $>0.05$ ). This results do not support the findings of Obadan (1997) and Meier (1989), who point out the negative relationship between economic growth and unemployment.

Table 2. Regression analysis result of model 1

\begin{tabular}{|c|c|c|c|c|c|c|c|}
\hline \multirow[b]{2}{*}{ Model 1} & \multicolumn{2}{|c|}{ Unstandardized Coefficients } & \multirow{2}{*}{$\begin{array}{c}\text { Standardized Coefficients } \\
\text { Beta } \\
\end{array}$} & \multirow{2}{*}{$\mathrm{t}$} & \multirow{2}{*}{ Sig. } & \multicolumn{2}{|c|}{ Collinearity Statistics } \\
\hline & $\mathrm{B}$ & Std. Error & & & & Tolerance & VIF \\
\hline (Constant) & -4.090 & 8.875 & & -0.461 & 0.645 & & \\
\hline Unemployment rate & -0.477 & 0.620 & -0.063 & -0.769 & 0.442 & 0.594 & 1.685 \\
\hline Poverty rate & 0.004 & 0.090 & 0.004 & 0.044 & 0.965 & 0.451 & 2.215 \\
\hline $\ln P E$ & -1.187 & 0.648 & -0.126 & -1.832 & 0.068 & 0.848 & 1.179 \\
\hline LnEI & -0.020 & 0.237 & -0.007 & -0.083 & 0.934 & 0.624 & 1.602 \\
\hline LnPI & $2.486^{*}$ & 0.893 & 0.258 & 2.784 & 0.006 & 0.466 & 2.147 \\
\hline $\mathrm{R}=0.218$ & \multicolumn{2}{|c|}{$\mathrm{R}$ Square $=0,048$} & & & & & \\
\hline \multicolumn{8}{|c|}{ Adjusted R Square $=0,028$} \\
\hline $\mathrm{F}=2.394$ & \multicolumn{2}{|c|}{ Sig. $=0,038$} & & & & & \\
\hline
\end{tabular}

\subsection{Model 2 Where Poverty Rate Is Dependent Variable}

The model is statistically significant at the significance level of $99 \%$ (sig. F-test $=0.000$ ). Adjusted R Square is $39.6 \%$, indicates that this model shows relatively efficient results of unemployment rate change. 03 independent variables of poverty rate; export \& import value; and public investment is significant at the significance level of 99\% (sig. t-test $<1 \%$ ). There is a negative relationship between poverty rate; and export \& import value with unemployment rate.

The higher poverty rate is; the lower unemployment rate is. Many researches indicate that there is a positive relationship between unemployment rate with poverty rate (Todaro, 1985). In addition, the negative relationship between export \& import value with unemployment means that export development contributes to unemployment reduction by providing a great number of jobs. 
Our results show that public investment has a significant and positive impact on unemployment at provincial level in Vietnam (significance level of 99\%). This means that public investment efficiency is still low in Vietnam; the higher public investment is; the higher unemployment rate is. According to our results, the other dependent variables of economic growth and public expenditure do not have significant impact on unemployment rate of Vietnam provinces (sig. t-test $>0.05$ ).

In general, the empirical research findings in Vietnam for the period of 2012-2015 has not demonstrated the relationship between economic growth with unemployment (with explanatory variable of economic growth). Meanwhile, the negative relationship between economic growth with unemployment is indicated in several previous researches. Al-Habees and Rumman (2012) find that high economic growth contributes to unemployment reduction in his research of Caribe.

Table 3. Regression analysis result of model 2

\begin{tabular}{|c|c|c|c|c|c|c|c|}
\hline \multirow[b]{2}{*}{ Model 2} & \multicolumn{2}{|c|}{ Unstandardized Coefficients } & \multirow{2}{*}{$\begin{array}{c}\text { Standardized Coefficients } \\
\text { Beta }\end{array}$} & \multirow{2}{*}{$\mathrm{t}$} & \multirow{2}{*}{ Sig. } & \multicolumn{2}{|c|}{ Collinearity Statistics } \\
\hline & $\mathrm{B}$ & Std. Error & & & & Tolerance & VIF \\
\hline (Constant) & 0.963 & 0.923 & & 1.043 & 0.298 & & \\
\hline GDP growth & -0.005 & 0.007 & -0.039 & -0.769 & 0.442 & 0.955 & 1.047 \\
\hline Poverty rate & $-0.075^{* * *}$ & 0.008 & -0.592 & -9.338 & 0.000 & 0.616 & 1.623 \\
\hline $\operatorname{lnPE}$ & -0.003 & 0.068 & -0.002 & -0.038 & 0.970 & 0.837 & 1.195 \\
\hline LnEI & $-0.085 * * *$ & 0.024 & -0.218 & -3.553 & 0.000 & 0.657 & 1.522 \\
\hline LnPI & $0.254 * * *$ & 0.093 & 0.199 & 2.726 & 0.007 & 0.465 & 2.150 \\
\hline $\mathrm{R}=0.639$ & \multicolumn{2}{|c|}{ R Square $=0,408$} & & & & & \\
\hline \multicolumn{8}{|c|}{ Adjusted R Square $=0,396$} \\
\hline $\mathrm{F}=32.929$ & \multicolumn{2}{|c|}{ Sig. $=0,000$} & & & & & \\
\hline
\end{tabular}

\subsection{Model 3 Where Unemployment Rate Is Dependent Variable}

The model is statistically significant at the significance level of $99 \%$ (sig. F-test $=0.000$ ). Adjusted R Square is $54.3 \%$, indicates that this model shows relatively efficient results of poverty rate change.

Table 4. Regression analysis result of model 3

\begin{tabular}{|c|c|c|c|c|c|c|c|}
\hline \multirow[b]{2}{*}{ Model 3} & \multicolumn{2}{|c|}{ Unstandardized Coefficients } & \multirow{2}{*}{$\begin{array}{c}\text { Standardized Coefficients } \\
\text { Beta }\end{array}$} & \multirow{2}{*}{$\mathrm{t}$} & \multirow{2}{*}{ Sig. } & \multicolumn{2}{|c|}{ Collinearity Statistics } \\
\hline & $\mathrm{B}$ & Std. Error & & & & Tolerance & $\mathrm{VIF}$ \\
\hline (Constant) & $49.854^{* * *}$ & 5.428 & & 9.184 & 0.000 & & \\
\hline GDP growth & 0.003 & 0.046 & 0.003 & 0.070 & 0.945 & 0.952 & 1.050 \\
\hline Unemployment rate & $-3.436^{* * *}$ & 0.377 & -0.437 & -9.124 & 0.000 & 0.816 & 1.225 \\
\hline $\operatorname{lnPE}$ & 0.087 & 0.465 & 0.009 & 0.187 & 0.852 & 0.837 & 1.195 \\
\hline LnPI & $-2.908 * * *$ & 0.606 & -0.290 & -4.797 & 0.000 & 0.513 & 1.949 \\
\hline LnExport & $-0.709 * * *$ & 0.157 & -0.235 & -4.524 & 0.000 & 0.691 & 1.447 \\
\hline $\mathrm{R}=0.743$ & \multicolumn{2}{|c|}{ R Square $=0,552$} & & & & & \\
\hline \multicolumn{8}{|c|}{ Adjusted R Square $=0,543$} \\
\hline $\mathrm{F}=58.983$ & \multicolumn{2}{|l|}{ Sig. $=0,000$} & & & & & \\
\hline
\end{tabular}

Unemployment rate; Export \& Import value; and Public investment are 03 independent variables at the significance level of $99 \%$ (sig. t-test $<1 \%$ ). These variables have a negative relationship with poverty. The higher poverty rate is; the higher unemployment rate is. This result supports the finding of model 2 and many previous researches. Thus, the growth of export and public investment contributes to economic development and poverty reduction. The other dependent variables of economic growth and public expenditure do not have 
significant impact on unemployment rate at provincial level in Vietnam (sig. t-test >0.05).

Thus, the finding does not demonstrate the relationship between economic growth and poverty rate (with explanatory variable of economic growth). Meanwhile, Obanda (1997) confirms the negative relationship between economic growth and poverty: in the long term, sustainable economic growth contributes to eliminating poverty.

In general, our empirical research of 245 year observations in 63 Vietnam provinces for the period of 2012-2015 tests the relationship among 06 macroeconomic variables: (i) Economic growth, (ii) Poverty rate; (iii) Unemployment rate; (iv) Public expenditure; (v) Export \& import value \& (vi) Public investment, at provincial level in Vietnam. Firstly, public investment has a positive impact on economic growth. Secondly, poverty, and export \& import have a negative impact on unemployment. Thirdly, public investment has a significant and positive impact on unemployment. Fourthly, unemployment; export \& import; and public investment have a negative impact on poverty.

\section{Implications of the Results}

From the research results mentioned above, we propose 03 groups of recommendations for sustainable economic growth, poverty reduction, and unemployment reduction, including:

\section{Group 1: Sustainable economic growth}

Firstly, Vietnam State and local authorities should improve administrative procedures according to Resolution No. 19/NQ-CP dated March 18th, 2014 by the Government On major tasks and solutions for improving the business environment and national competitiveness. Secondly, Vietnam State and firms need to increase industrial production, especially manufacturing and export processing. In addition, Vietnam State should take measures of stimulating domestic demand, expanding distribution network, and improving goods and service quality. Thirdly, Vietnam State needs to promote export and control import, as well as explore opportunities of free trade agreements (TPP, Vietnam - EU, ...). Fourthly, Vietnam State should accelerate the investment disbursement and encourage socio-economic infrastructure investment in the form of PPP (public private partnership). Fifthly, Vietnam State and local authorities needs to deploy effective measures to control the issues of environment and climate change.

\section{Group 2: Poverty reduction}

Firstly, Vietnam State needs to concentrate on infrastructure investment of poor provinces. This supports socio-economic development by improving goods competitiveness and facilitating goods transportation. 04 specific recommendations include: (i) Developing electricity network; (ii) Improving traffic system; (iii) Improving irrigation system; \& (iv) Developing communication network. Vietnam budget play an important role in recommendation success. Specifically, for the infrastructure development, Vietnam State needs to building and improving road; this supports production and living conditions of community. For improving irrigation system, the State and local authorities should encourage community support by donating 20-40\% of total new construction investment capital; and $20-40 \%$ of maintenance costs. Secondly, Vietnam State needs to accelerate industrialization and urbanization for unemployment reduction and raising the living standards of the poor people. Moreover, it is important to promote high technology industry and manufacturing industry for making use of resources, including human resource. The link between industry with small-scale industry needs developing. Vietnam State should encourage all economic components to support small and medium enterprises, and household ones.

\section{Group 3: Unemployment reduction}

Firstly, Vietnam State and relevant authorities need to reasonably adjust basic salary for unemployment reduction. Secondly, it is very essential to improve raining programs and vocational centers for increasing labor quality. Thirdly, monetary and fiscal policies need to involve in sustainable economic growth by encouraging firms to expand production and business, and attracting a lot of employees.

\section{Concluding Remarks}

Our empirical research of 245 year observations in 63 Vietnam provinces for the period of 2012-2015 focuses on the relationship among 06 variables, including: (i) Economic growth, (ii) Poverty rate; (iii) Unemployment rate; (iv) Public expenditure; (v) Export \& import value \& (vi) Public investment, at provincial level in Vietnam. Our findings indicate that: Firstly, public investment has a positive impact on economic growth. Secondly, poverty, and export \& import have a negative impact on unemployment. Thirdly, public investment has a significant and positive impact on unemployment. Fourthly, unemployment; export \& import; and public investment have a 
negative impact on poverty. On the basis of the results and actual situation, we propose 03 recommendation groups for sustainable economic growth, poverty reduction, and unemployment reduction of Vietnam provinces.

\section{References}

Alberto, J. I. M. (2014). Growth with Equity for the Development of Mexico: Poverty, Inequality, and Economic Growth (1992-2008). World Development, 59, 313-326. http://dx.doi.org/10.1016/j.worlddev.2014.01.011

Al-Habees, M. A., \& Rumman, A. M. (2012). The Relationship Between Unemployment and Economic Growth in Jordan and Some Arab Countries. World Applied Sciences Journal, 18(5), 673-680.

Amassoma, D. N., \& Philip, I. (2013). The Impact of Unemployment Rate on Productivity Growth in Nigeria. International Journal of Economics and Management Sciences, 2(5), 16-26.

Galbis, M. E. (2012). The Impact of TFP Growth on the Unemployment Rate: Does on-the-job Training Matter? CEPREMAP Working Papers (Docweb), No. 1207.

Herwartz, H., \& Niebuhr, A. (2011). Growth, Unemployment and Labour Market Institutions: Evidence from a Cross-Section of EU Regions. Applied Economics, 43(30), 4663-4676. http://dx.doi.org/10.1080/00036846.2010.493142

Marinko, S., \& Romina, P. D. (2015). Poverty and Economic Growth: A Review. Technological and Economic Development of Economy, 22(1), 156-175.

Moore, J. D., \& Donaldson, J. A. (2016). Human-Scale Economics: Economic Growth and Poverty Reduction in Northeastern Thailand. World Development, 85, 1-15. http://dx.doi.org/10.1016/j.worlddev.2016.04.004

Neto, A., \& Silva, S. T. (2013). Growth and Unemployment: A Bibliometric Analysis on Mechanisms and Methods. FEP Working Papers Faculdade de Economia da Universidade do Porto, No. 498.

Nikolli, E. (2014). Economic growth and unemployment rate: Case of Albania. European Journal of Social Sciences Education and Research, 1(1).

Okun, A. M. (1962). Potential GNP: Its Measurement and Significance. Proceedings of the Business and Economic Statistics Section of the American Statistical Association. American Statistical Association, Washington, DC, 1962, pp. 98-104.

Parello, C. P. (2010). A Schumpeterian Growth Model with Equilibrium Unemployment. Metroeconomica, 61(2), 398-426. http://dx.doi.org/10.1111/j.1467-999X.2009.04076.x

Sezgin, F. H., Topkaya, Ö., \& Özel, H. A. (2013). Investigation of Economic Growth and Unemployment Relationship for G7 Countries Using Panel Regression Analysis. International Journal of Business \& Social Science, 4(6).

\section{Copyrights}

Copyright for this article is retained by the author(s), with first publication rights granted to the journal.

This is an open-access article distributed under the terms and conditions of the Creative Commons Attribution license (http://creativecommons.org/licenses/by/4.0/). 